\title{
Accounts
}

\section{Inorganic and Transition Metal Azides}

\author{
Won K. Seok* and Thomas M. Klapötke ${ }^{\dagger}$ \\ Department of Chemistry, Dongguk University, 26 Pil-Dong, Chung-Ku, Seoul 100-715, South Korea \\ ${ }^{*}$ E-mail: wonkseok@dongguk.edu \\ ${ }^{\dagger}$ Department of Chemistry, University of Munich (LMU), Butenandtstr. 5-13 (D), 81377 Munich, Germany \\ ${ }^{*}$ E-mail:tmk@cup.uni-muenchen.de \\ Received December 6, 2009, Accepted January 6, 2010
}

\begin{abstract}
Experimental and theoretical studies show that all covalent azides possess a nonlinear azide group. They also rationalize this remarkable structural feature. We have seen that the most important non-covalent contributions in the covalently bound azides system (X-N1-N2-N3) are the $\pi$-delocalization over the entire molecule and a strong negative hyperconjugation which donates electron density from the filled $\sigma$ (X-N1) orbital into the unfilled, antibonding $\pi^{*}$ (N2-N3) orbital. For transition metal azide complexes, a bent configuration and a small difference between the N-N bond lengths, generally the longer one being adjacent to the transition metal, were observed.
\end{abstract}

Key Words: Covalent inorganic azides, Transition metal azide complexes, ${ }^{14} \mathrm{~N}$ NMR spectrum

\section{Introduction}

The types of multiply bonded ligand to the metal have been originated from the investigation of active site of biologically interesting enzymes such as the nitrite reductase and cytochrome $\mathrm{P}_{450 .}{ }^{1-2}$ The six-electron reduction of nitrite to ammonia catalyzed by the nitrite enzyme is an important step in green plants, the cycle shows the presence of triply bonded nitrogen atom to the transition metal. ${ }^{3}$ The enzyme nitrogenase is also vital in converting inorganic nitrogen gas to a form usable by living organism. In the catalytic cycle of the reaction of the transfer of an oxygen atom into various substrates by cytochrome oxidase, an oxoiron(IV) porphyrin $\pi$-cation radical intermediate is believed to be involved. ${ }^{2}$ The preparations of terminal oxo and nitrido complexes have been focused by many researchers since then. ${ }^{4}$ It demonstrates that the transition metal azides have been a crucial precursor to the metal-nitrogen bonded compounds. From the point of coordination chemistry, the strong trans effect of the oxo/nitrido ligand plays an important role in determining stereochemistry and, presumably, substitution rate. ${ }^{4 a}$

Since the discovery of the first molecular nitrogen complexes, metal complexes of dinitrogen have been intensively examined. ${ }^{5-7}$ Generally one route to the formation of metal nitrogen species is via the redox reaction of the corresponding metal azide species. The chemistry of covalent inorganic azides originated with the synthesis of aqueous $\mathrm{HN}_{3}$ solutions by Tony Curtius in $1890{ }^{8}$ A little later, in 1900 , it proved possible to prepare iodine azide as the first member of the now complete series of halogen azides. ${ }^{9}$ Although reviews and monographs of azido species have already been appeared, ${ }^{10}$ in this account, we summarize articles including our recent results on inorganic covalent azides and transition metal azide complexes.

\section{Synthesis}

The strategy of preparations of many covalent azide species has already been reviewed and showed that their synthesis should be performed with extreme care and the scale be as

Won K. Seok earned his BS degree from Seoul National University in 1979 and his MS degree from KAIST in 1981. He was a full-time instructor at Donga University from 1981-1984. In 1988, he received his PhD degree in inorganic chemistry from the Department of Chemistry, University of North Carolina at Chapel Hill under supervision of Prof. Thomas J. Meyer. From 1988-1990, he conducted his postdoctoral research with Prof. James A. Ibers at Northwestern University, USA. He was appointed to Assistant, Associate, and Professor at Dongguk University in Seoul from 1990 to present. He has been a visiting scholar at University of Pennsylvania from 1997 to 1998 . He served as a Vice-President of the Korean Chemical Society (2008). His research interest is focused on the development of new ruthenium dyes in dye-sensitized solar cells, azide chemistry and the pursuit of reaction mechanisms using new oxidants.

Thomas M. Klapötke received his PhD (1986), and Habilitation (1990) from the TU Berlin. From 1995-1997 he was Ramsay Professor of Chemistry at Glasgow University. In 1997, he moved to the University of Munich as Professor and Chair of Inorganic Chemistry. He was a Wilsmore Fellow at the University of Melbourne, Australia (1997/98 and 1999) and is a Visiting Professor at the Center of Energetic Concepts Development at the University of Maryland (2008-) and a Visiting Senior Scientist at the Energetics Technology Center in La Plata, MD (2008-). His scientific interests include primary and secondary explosives, pyrotechnics, propellant charges, high energy-density materials, computational chemistry, azide chemistry, fluorine chemistry, strong oxidizers, and nitro chemistry. Most of his applied work is done in collaboration with US and German military institutions. He is an author or co-author of 450 papers, 17 book chapters, and four monographs and textbooks. 
small as feasible. ${ }^{10-11}$

Most covalent azides are highly explosive, especially in pure form. It is therefore imperative that work on a preparative scale is performed under appropriate safety precautions, such as face shields, protective leather clothing, gloves, and ear protection. Experiments should also be performed on as small a scale as feasible. All halogen azides are very sensitive in this respect. Chlorine azide and bromine azide are particularly sensitive to small pressure variations and regularly explode at pressure changes of as little as 0.05 Torr.

Hydrazoic acid and many of its covalent inorganic (e.g., $\mathrm{CIN}_{3}$, $\mathrm{Me}_{3} \mathrm{SiN}_{3}$ ) and organic derivatives (e.g., $\mathrm{CH}_{3} \mathrm{~N}_{3}$ ) are also very toxic. $\mathrm{HN}_{3}$ is as poisonous as hydrogen cyanide. The halogen azides can best be prepared as shown in the following equations: ${ }^{10}$

$$
\begin{aligned}
& 4 \mathrm{HN}_{3}(\mathrm{~g})+2 \mathrm{~F}_{2}(\mathrm{~g}) \rightarrow 3 \mathrm{FN}_{3}(\mathrm{~g})+\mathrm{N}_{2}(\mathrm{~g})+\mathrm{NH}_{4} \mathrm{~F}(\mathrm{~s}) \\
& \mathrm{NaN}_{3}(\mathrm{~s})+\mathrm{Cl}_{2}(\mathrm{~g}) \rightarrow \mathrm{ClN}_{3}(\mathrm{l})+\mathrm{NaCl}(\mathrm{s}) \\
& \mathrm{NaN}_{3}(\mathrm{~s})+\mathrm{Br}_{2}(\mathrm{~g}) \rightarrow \mathrm{BrN}_{3}(\mathrm{l})+\mathrm{NaBr}(\mathrm{s}) \\
& \operatorname{AgN}_{3}(\mathrm{~s})+\mathrm{I}_{2}(\mathrm{sol}) \quad \rightarrow \quad \mathrm{IN}_{3}(\mathrm{sol})+\operatorname{AgI}(\mathrm{s})
\end{aligned}
$$

The transition metal azide complexes with coordinating ligand are relatively stable even to be isolated at room temperature under air, though most of them are thermally unstable with respect to the elimination of $\mathrm{N}_{2}$. It also turned out that the binary azide salts containing large bulky cations are thermally more stable and less explosive. ${ }^{12 \mathrm{f}}$

They have been generally obtained by the reaction of $\mathrm{MCl}_{\mathrm{n}}$, $\mathrm{MOCl}_{\mathrm{n}}$, or $\mathrm{LMCl}_{\mathrm{n}}(\mathrm{M}=$ metal, $\mathrm{L}=$ coordinating ligand $)$ with covalent inorganic azides. ${ }^{12-13}$ Also ionic azide reagents like $[\mathrm{A}]^{+}\left[\mathrm{N}_{3}\right]^{-}\left(\mathrm{A}=\mathrm{Na}, \mathrm{PPh}_{4}, \mathrm{NEt}_{4}\right)$ are useful to transfer the azide ligand to the transition metal site. ${ }^{14}$

$$
\begin{array}{r}
{\left[\mathrm{MCl}_{\mathrm{n}}\right],\left[\mathrm{MOCl}_{\mathrm{n}}\right],\left[\mathrm{LMCl}_{\mathrm{n}}\right] \stackrel{\mathrm{ClN}_{3}, \mathrm{Me}_{3} \mathrm{SiN}_{3},[\mathrm{~A}]^{+}\left[\mathrm{N}_{3}\right]^{-}}{\longrightarrow}} \\
{\left[\mathrm{MCl}_{\mathrm{n}-1}\left(\mathrm{~N}_{3}\right)\right],\left[\mathrm{MOCl}_{\mathrm{n}-1}\left(\mathrm{~N}_{3}\right)\right],\left[\mathrm{LMCl}_{\mathrm{n}-1}\left(\mathrm{~N}_{3}\right)\right]}
\end{array}
$$

Transition metal chlorate complexes can react with $\mathrm{NaN}_{3}$ in the presence of a ligand $\mathrm{L}$ in a polar solvent, which afford azide complexes very easily. ${ }^{15}$

$$
\left[\mathrm{M}\left(\mathrm{ClO}_{4}\right)_{2}\right]+\mathrm{L}+\mathrm{NaN}_{3} \rightarrow\left[\mathrm{M}\left(\mathrm{N}_{3}\right)_{2}(\mathrm{~L})_{4}\right](\mathrm{M}=\mathrm{Co}, \mathrm{Mn})
$$

Another way to prepare the transition metal azide complexes is using the reaction of the oxo compounds with $\mathrm{Me}_{3} \mathrm{SiN}_{3}$, the bis(azido) complexes were readily obtained in this case. ${ }^{16}$

$$
\left[\left(\mathrm{Cp}^{*}\right)_{2} \mathrm{Mo}(\mathrm{O})\right]+\mathrm{Me}_{3} \mathrm{SiN}_{3} \rightarrow\left[\left(\mathrm{Cp}^{*}\right)_{2} \mathrm{Mo}\left(\mathrm{N}_{3}\right)_{2}\right]
$$

\section{${ }^{14}$ N NMR Spectroscopy}

To characterize the azide species in solution, ${ }^{14} \mathrm{~N}$ NMR spectrometry is verified as one of the most suitable and invaluable methods. In addition, this technique could be utilized to obtain equilibrium constants and thermodynamic parameters. ${ }^{17 \mathrm{a}}$
Table 1. ${ }^{14} \mathrm{~N}$ NMR Chemical shifts $\left(\delta\right.$ in ppm) and line widths $\left(\Delta v_{1 / 2}\right.$ in $\mathrm{Hz}$, in parentheses) of covalent azide compounds (M-N1-N2-N3) and $\mathrm{NaN}_{3}$ for comparison

\begin{tabular}{lcccl}
\hline Compound & $\begin{array}{c}\delta(\mathrm{N} 1) \\
\left(\Delta v_{1 / 2}\right)\end{array}$ & $\begin{array}{c}\delta(\mathrm{N} 2) \\
\left(\Delta v_{1 / 2}\right)\end{array}$ & $\begin{array}{c}\delta(\mathrm{N} 3) \\
\left(\Delta v_{1 / 2}\right)\end{array}$ & Solvent \\
\hline $\mathrm{NaN}_{3}$ & & $-128(30)$ & $-277(65)$ & $\mathrm{D}_{2} \mathrm{O}$ \\
$\mathrm{Me}_{3} \mathrm{SiN}_{3}$ & $-316(200)$ & $-142(35)$ & $-205(35)$ & $\mathrm{CDCl}_{3}$ \\
$\mathrm{Me}_{2} \mathrm{AsN}_{3}$ & $-313(300)$ & $-132(50)$ & $-192(90)$ & $\mathrm{CDCl}_{3}$ \\
$\mathrm{MeAs}\left(\mathrm{N}_{3}\right)_{2}$ & $-298(200)$ & $-129(30)$ & $-169(70)$ & $\mathrm{SO}_{2}$ \\
$\mathrm{As}\left(\mathrm{N}_{3}\right)_{3}$ & $-318(150)$ & $-131(15)$ & $-165(30)$ & $\mathrm{CDCl}_{3}$ \\
{$\left[\mathrm{As}\left(\mathrm{N}_{3}\right)_{4}\right]^{+}\left[\mathrm{AsF}_{6}\right]^{-}$} & $-280(375)$ & $-135(30)$ & $-162(125)$ & $\mathrm{SO}_{2}$ \\
\hline
\end{tabular}

For many covalent azides and transition metal azide species, three well-resolved resonances in the ${ }^{14} \mathrm{~N}$ NMR spectrum have been observed, which have been assigned to the chemically inequivalent nitrogen atoms of $\mathrm{N} 1, \mathrm{~N} 2$, and $\mathrm{N} 3$ in the connectivity of [(L)M-N1-N2-N3]. ${ }^{10 a}$ For example, the ${ }^{14}$ N NMR spectrum of $[\text { (tpy)(phen)Rh-N1-N2-N3 }]^{2+}\left(\right.$ tpy $=2,2^{\prime}: 6^{\prime}, 2^{\prime \prime}$-terpyridine, phen $=1,10$-phenanthroline) in $\mathrm{CD}_{3} \mathrm{CN}$ shows the resonances of N1, N2, and N3 at $-336,-134,-250 \mathrm{ppm}$, each correspond to nitrogen atom of the azide group coordinated to the Rh metal. ${ }^{12 \mathrm{e}}$ The nitrogen atoms of the polypyridyl ligands could be observed around -163 ppm as a broad peak. It should be noted that the relative line-widths in the spectra are related to the local symmetry around the nitrogen atom with highly symmetric $\mathrm{N}$ atoms, the more symmetric $\mathrm{N}$ atoms, and the very asymmetric $\mathrm{N}$ atoms. ${ }^{12 \mathrm{e}}$ Because of the large quadrupole moment of the nitrogen nucleus, ${ }^{14} \mathrm{~N}-{ }^{14} \mathrm{~N}$ couplings were negligible.

Also in the area of main-group azide chemistry, ${ }^{14} \mathrm{~N}$ NMR spectroscopy has proved to be of great value. For example, several $\mathrm{As}(\mathrm{III})$ and $\mathrm{As}(\mathrm{V})$ azide species have been characterized in solution using ${ }^{14} \mathrm{~N}$ NMR spectroscopy. ${ }^{17 \mathrm{~b}}$

The solution ${ }^{14} \mathrm{~N}$ NMR spectra of all azidoarsines and also of the azidoarsonium cation show three distinct ${ }^{14} \mathrm{~N}$ NMR resonances, thus, it can now unambiguously be stated that these compounds dissolve monomerically without azide bridging or azide exchange between the organo arsenic moieties.

\section{Structure and Bonding}

Over the years the structures of several covalently bound azides have been determined experimentally by microwave spectroscopy (MW) or by X-ray diffraction (XRD) or electron diffraction (ED) techniques. Examples are $\mathrm{HN}_{3}(\mathrm{MW}),{ }^{18}$ and $\mathrm{H}_{2} \mathrm{~N}_{3}^{+}$(XRD), ${ }^{19} \mathrm{NCN}_{3}$ (MW), ${ }^{20} \mathrm{CF}_{3} \mathrm{~N}_{3}$ (ED, MW), ${ }^{21} \mathrm{H}_{3} \mathrm{SiN}_{3}$ (MW) and $\mathrm{H}_{3} \mathrm{GeN}_{3}(\mathrm{ED}),{ }^{22-23} \mathrm{FN}_{3}(\mathrm{MW})$ and $\mathrm{CIN}_{3}(\mathrm{MW})^{24-25}$ as well as $\mathrm{Te}\left(\mathrm{N}_{3}\right)_{3}{ }^{+}$(XRD). ${ }^{26}$ Recently the structures of several kinetically stabilized azides have been determined; examples are $\left(\mathrm{CF}_{3}\right) \mathrm{As}\left(\mathrm{N}_{3}\right)_{2}(\mathrm{ED})$ and $\left(\mathrm{CF}_{3}\right)_{2} \mathrm{As}\left(\mathrm{N}_{3}\right)(\mathrm{ED}){ }^{27-29}$

When discussing the electronic structure of $\mathrm{HN}_{3}$, Glukhovtsev and Schleyer have made the sensible distinction between geometric hypervalence and electronic hypervalence. ${ }^{30}$ Thus, the calculated (HF/6-31G*//MP2/6-31G*) N-N bond lengths in $\mathrm{HN}_{3}$ of 1.250 (central) and 1.158 (terminal) $\AA$ are similar to the calculated values $\left(\mathrm{HF} / 6-31 \mathrm{G}^{*} / / \mathrm{MP} 2 / 6-31 \mathrm{G}^{*}\right)$ of 1.265 and $1.130 \AA$ for the N-N double and triple bonds of $\mathrm{HNNH}$ and $\mathrm{N}_{2}$, respectively. ${ }^{30}$ Therefore, $\mathrm{HN}_{3}$ is an example of a molecule 


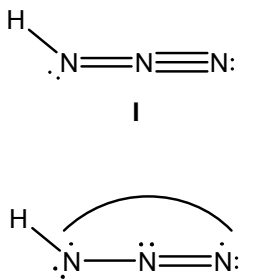

IIIa

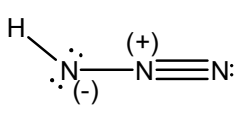

IV
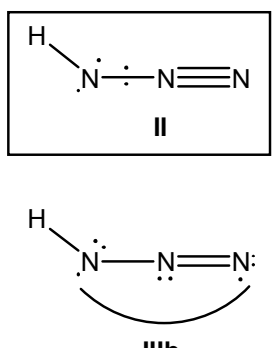

IIIb

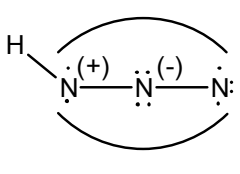

V
Scheme 1

whose bond lengths suggest that the central nitrogen is apparently pentavalent, as indicated in the classical VB structure I (Scheme 1). ${ }^{31}$ However, unless the nitrogen atom expands its valence shell, the $\pi$ bonds of this structure are fractional electron-pair bonds. The increased-valence structure II, with fractional electron-pair bonds and 1-electron bonds, also involves an apparent pentavalence. Some of the properties of these two VB structures can be used to restate the nature of the origin of the apparent electronic pentavalence for nitrogen, namely appreciable contributions of Dewar-type structures such as III to the component Lewis structure resonance scheme. ${ }^{31}$ Structure II is an example of an increased-valence structure, ${ }^{32-34}$ and is equivalent to resonance between the canonical Lewis structures IIIa, IIIb, IV and V, when the wave functions for the bonds of structure IV are formulated using the Heitler-London procedure. When LMOs (London Molecular Orbital) are used to accommodate the electrons of these bonds, II is equivalent to resonance between 25(!) canonical Lewis structures. ${ }^{35}$

Despite the relatively strong N1-N2 bond in $\mathrm{HN}_{3}$, thermal fragmentation of this molecule is not induced by breaking the $\mathrm{H}-\mathrm{N}_{3}$ bond but rather by dissociation into $\mathrm{HN}$ and $\mathrm{N}_{2}$. Since the electronic ground state of $\mathrm{XN}(\mathrm{X}=\mathrm{H}$, halogen $)$ is a triplet state $\left({ }^{3} \Sigma^{-}\right)$, dissociation of $\mathrm{XN}_{3}\left({ }^{1} \mathrm{~A}^{\prime}\right)$ into $\mathrm{XN}\left({ }^{3} \Sigma^{-}\right)$and $\mathrm{N}_{2}\left({ }^{1} \Sigma_{\mathrm{g}}^{+}\right)$ is spin-symmetry forbidden. Nevertheless, pyrolysis experiments have shown that $\mathrm{HN}_{3}$ decomposes into $\mathrm{N}_{2}$ and $\mathrm{HN}$ in the ground-state triplet $\left({ }^{3} \Sigma^{-}\right)$state. ${ }^{36}$ A theoretical study ${ }^{37}$ on the energetics of the dissociation reaction of $\mathrm{HN}_{3}\left({ }^{1} \mathrm{~A}^{\prime}\right)$ yielding $\mathrm{N}_{2}\left({ }^{1} \Sigma_{\mathrm{g}}^{+}\right)$and $\mathrm{HN}\left({ }^{3} \Sigma^{-}\right)$at a very high level of theory using CASSCF and MCSCF-CI techniques has shown that singlettriplet coupling occurs because the $\mathrm{HN}_{3}$ wave function in the region of the transition state can be considered an equal mixture of $\mathrm{N}_{2}(\mathrm{X}) \cdot \mathrm{NH}\left(\mathrm{a}^{1} \Delta\right)$ and $\mathrm{N}_{2}(\mathrm{X}) \cdot \mathrm{NH}\left(\mathrm{b}^{1} \Delta\right)$. The calculated barrier for the dissociation $\left(35.7 \mathrm{kcal} \mathrm{mol}^{-1}\right)$ is in excellent agreement with the value of $36 \mathrm{kcal} \mathrm{mol}^{-1}$ estimated from thermal dissociation studies. ${ }^{38}$ This result suggests that the stabilities of $\mathrm{XN}_{3}$ molecules may be determined by the activation barrier for breaking the $\mathrm{XN}-\mathrm{N}_{2}$ bond, which in turn involves singlettriplet coupling along the reaction course. The accurate calculation of the dissociation barrier of $\mathrm{XN}_{3}$ yielding $\mathrm{XN}$ and $\mathrm{N}_{2}$ needs a very high level of theory that is not possible for larger

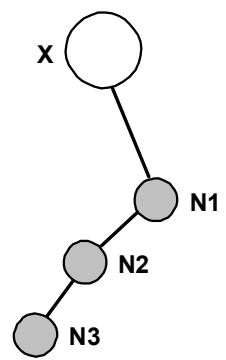

Figure 1. Depiction of a covalent $\mathrm{XN}_{3}$ azide in the trans-bent $C_{\mathrm{S}}$ conformation.

atoms or substituent groups $\mathrm{X}$ at present time. However, Frenking et al. have shown that for halogen azides $\mathrm{XN}_{3}(\mathrm{X}=$ halogen) the reaction energy of the dissociation reaction of $\mathrm{XN}_{3}$ $\left({ }^{1} \mathrm{~A}^{\prime}\right)$ yielding $\mathrm{N}_{2}\left({ }^{1} \Sigma_{\mathrm{g}}^{+}\right)$and $\mathrm{XN}\left({ }^{3} \Sigma^{-}\right)$can be calculated at the electron-correlated MP2 level of theory using effective core potentials for the heavy elements MP2/LANL1DZ+P. ${ }^{39}$ Generally, the agreement between the theoretical and experimental data for the heat of formation calculated at the MP2 level (DZ+P basis set) is very good for $\mathrm{HN}_{3}{ }^{40}$ This gives credence to those calculated dissociation energies for which there are no experimental data due to the extreme lability of the compounds in question.

Even then years ago structural data (experimental and theoretical) on covalent azides were very rare due to the explosive nature of these compounds and to limited computer power. In one of the early papers reporting on the experimental structure determination of $\mathrm{CF}_{3} \mathrm{~N}_{3}$, Christe et al. correctly stated that one of the most significant features of the $\mathrm{CF}_{3} \mathrm{~N}_{3}$ structure was the nonlinearity of the $\mathrm{N}_{3}{ }^{21}$ The same authors, however, also pointed out that it should be kept in mind that the value of the NNN angle carries a rather large uncertainty. Today we know from experimental and theoretical studies that, in contrast to the azide anion $\left(\mathrm{N}_{3}{ }^{-}, D_{\infty h}\right)$, all covalent azides possess a nonlinear azide group, and we can understand or at least rationalize this remarkable structural feature.

There is probably no class of covalent azides that has been studied more comprehensively than the halogen azides. The structures of all members of this $\mathrm{XN}_{3}$ family $\left(\mathrm{X}=\mathrm{F},{ }^{24} \mathrm{Cl},{ }^{25} \mathrm{Br},{ }^{41}\right.$ and $\mathrm{I}^{42-46}$ ) were determined experimentally and were computed at high levels of theory. Among the halogen azides iodine azide is, in terms of its structure and bonding, probably the most studied compound. ${ }^{42-46}$ Experimentally the structure of $\mathrm{IN}_{3}$ was determined in the solid state (X-ray) ${ }^{42}$ as well as in the gas phase $(\mathrm{ED}, \mathrm{MW})^{43-44}$ and several ab initio and DFT computations have been reported. ${ }^{12 b, 39,42}$

$\mathrm{HN}_{3}$ and halogen azides $\mathrm{X}-\mathrm{N1}-\mathrm{N} 2-\mathrm{N} 3$ present as discrete monomeric species in the gas phase display a bent trans $C_{s}$ configuration with an N1-N2-N3 bond angle of $172 \pm 3^{\circ}$, and two significantly different $\mathrm{N}-\mathrm{N}$ bond lengths $(\mathrm{N} 1-\mathrm{N} 2=1.24$ (2) $\AA, \mathrm{N} 2-\mathrm{N} 3=1.160$ (5) $\AA$, Fig. 1). Generally, the agreement between the experimental and computed data is good. It proved to be very helpful to introduce quasi-relativistic pseudo-potentials for the heavy halogens $\mathrm{Br}$ and I to account for relativistic effects. For instance, calculations utilizing an effective core potential often led to better results in less time than all-electron 
Table 2. Average deviations of ab initio and DFT-computed structural parameters of four atomic covalent azides $\mathrm{XN}_{3}(\mathrm{X}=\mathrm{H}, \mathrm{F}, \mathrm{Cl}$, $\mathrm{Br}$, I) from the experimentally observed data. ${ }^{47 \mathrm{a}, \mathrm{b}}$

\begin{tabular}{lllll}
\hline & HF & MP2 & B & B-LYP \\
\hline$\Delta \mathrm{r} / \AA$ & 0.03 & 0.03 & 0.06 & 0.03 \\
$\Delta</^{\circ}$ & 2.8 & 1.5 & 1.5 & 1.5
\end{tabular}<smiles>[X][N+]#[N+]</smiles>

Scheme 2

computations. ${ }^{10 \mathrm{a}}$ Table 2 shows the average differences between the experimentally observed and computed structural parameters for the halogen azides. Usually ab initio HF calculations give bond distances that are too short, whereas DFT computations predict distances that are somewhat too long. It can be concluded that the uncorrelated ab initio (HF) and DFT (B) calculations are of similar quality. The density functional computation usually gives better bond angles but the HF method results in better distances and vice versa. On correlated levels both methods - ab initio (MP2) and DFT (B-LYP) - compare nicely with the experimental data. ${ }^{12 \mathrm{~b}, 47}$

At this stage we know that among the four-atomic $\mathrm{XN}_{3}$ species there is excellent agreement between computed and experimentally observed structural parameters. Undoubtedly the $\mathrm{N}_{3}$ unit is bent and there are always two different N-N bond lengths ( $c f$. VB discussion of $\mathrm{HN}_{3}$, see above). But how can we explain these features? The localization procedure of covalent $\mathrm{XN}_{3}$ azides results in an NBO (natural bond orbital) analysis that yields the configuration VI as the energetically most favorable Lewis structure. According to this, there is a single bond between $\mathrm{N} 1$ and N2 and a triple bond between N2 and N3.

Whereas the observed values for the N2-N3 bond really correspond to a (weak) triple bond, the N1-N2 bond in terms of its length resembles rather more a double than a single bond (typical experimental values: N-N single bond, $1.449 \AA ; \mathrm{N}=\mathrm{N}$ double bond, $1.252 \AA$; $\mathrm{N} \equiv \mathrm{N}$ triple bond, $1.098 \AA \AA^{48-50}$ If we now allow for the non-covalent effects that are ignored in the "natural" Lewis picture by a second order perturbation cal-

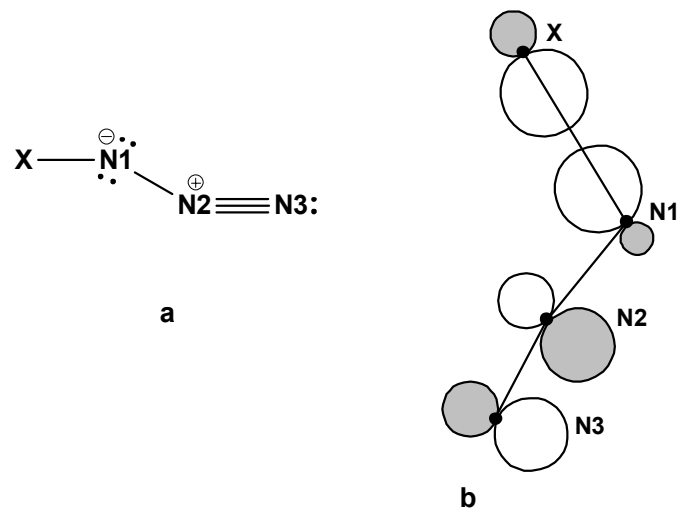

Figure 2. Negative $\sigma(\mathrm{X}-\mathrm{N} 1) \rightarrow \pi^{*}(\mathrm{~N} 2-\mathrm{N} 3)$ hyperconjugation in $\mathrm{XN}_{3}$.

culation, two significant results can be obtained: (i) The most important non-covalent contributions in the $\mathrm{XN}_{3}$ system are the $\pi$-delocalization over the entire molecule (resonance). This explains the planarity of the molecule (i.e. $C_{\mathrm{s}}$ symmetry). (ii) There is a strong negative hyperconjugation (intramolecular donor-acceptor interaction $)^{51-52}$ which donates electron density from the filled $\sigma(\mathrm{X}-\mathrm{N} 1)$ orbital into the unfilled, antibonding $\pi^{*}(\mathrm{~N} 2-\mathrm{N} 3)$ orbital (Fig. 2). This weakens the X-N1 and N2-N3 bonds, while it strengthens the N1-N2 bond. Moreover, from the pictorial approach of the orbitals shown in Figure 2 one can see that a trans-bent conformation favors the hyperconjugative $\sigma(\mathrm{X}-\mathrm{N} 1) \rightarrow \pi^{*}(\mathrm{~N} 2-\mathrm{N} 3)$ overlap (A VB rationalization for the N1-N2-N3 bending is provided in Table 2 of ref. $47 \mathrm{a}$ ).

Compared to ionic $[\mathrm{A}]^{+}\left[\mathrm{N}_{3}\right]^{-}$and covalent inorganic $\mathrm{XN}_{3}$ azides, covalently bound azide to the transition metal species show a bent configuration and a small difference between the $\mathrm{N}-\mathrm{N}$ bond lengths, generally the longer being adjacent to the transition metal. Table 3 shows a - by no means complete - list of representative examples of azide, bridged azide, bis(azide), tris(azide), and tetrakis(azide) transition metal complexes.

The distances of N1-N2 and N2-N3 are significantly shorter than a typical N-N single bond (1.44 $\AA$ ) and slightly longer than the $\mathrm{N} \equiv \mathrm{N}$ triple bond $(1.098 \AA$ ), although the energetically most favorable Lewis structure shows a single bond between N1 and N2 and a triple bond between N2 and N3 from an NBO analysis. ${ }^{55}$ On the contrary to the non-covalent contributions in the covalent $\mathrm{XN}_{3}$ azides, there is $\pi$-delocalization over the

Table 3. Comparison of bond distances $[\AA]$ and angles $\left[{ }^{\circ}\right]$ for related transition metal azide(s) complexes containing various kind of ligands

\begin{tabular}{lccccc}
\hline \multicolumn{1}{c}{ Compound } & $\mathrm{d}(\mathrm{X}-\mathrm{N} 1)[\AA]$ & $\mathrm{d}(\mathrm{N} 1-\mathrm{N} 2)[\AA]$ & $\mathrm{d}(\mathrm{N} 2-\mathrm{N} 3)[\AA]$ & $<(\mathrm{N} 1, \mathrm{~N} 2, \mathrm{~N} 3)\left[{ }^{\circ}\right]$ & $<(\mathrm{X}, \mathrm{N} 1, \mathrm{~N} 2)\left[{ }^{\circ}\right]$ \\
\hline$\left[\mathrm{Cu}(\mathrm{trpn})\left(\mathrm{N}_{3}\right)\right]^{+}[12 \mathrm{~d}]$ & $2.044(5)$ & $1.184(7)$ & $1.145(7)$ & $176.0(7)$ & $130.9(5)$ \\
{$\left[\mathrm{Ru}(\mathrm{tpy})\left(\mathrm{PPh}_{3}\right)_{2}\left(\mathrm{~N}_{3}\right)\right]^{+}[12 \mathrm{c}]$} & $2.132(5)$ & $1.157(7)$ & $1.159(8)$ & $177.8(6)$ & $139.6(4)$ \\
{$\left[\mathrm{Rh}(\mathrm{tpy})(\mathrm{phen})\left(\mathrm{N}_{3}\right)\right]^{+}[12 \mathrm{e}]$} & $2.038(7)$ & $1.172(10)$ & $1.172(11)$ & $175.7(9)$ & $120.4(6)$ \\
{$\left[\mathrm{Ir}\left(\mathrm{Cp}{ }^{*}\right)(2-\mathrm{sqn})\left(\mathrm{N}_{3}\right)\right][53]$} & $2.132(6)$ & $1.178(7)$ & $1.127(7)$ & $175.4(7)$ & $127.3(4)$ \\
{$\left[\mathrm{Fe}(\mathrm{LDM})\left(\mathrm{N}_{3}\right)\right]_{2}[12 \mathrm{~g}]$} & $2.100(10)$ & $1.207(14)$ & $1.181(15)$ & $176.7(14)$ & $131.2(9)$ \\
{$\left[\mathrm{Co}(\mathrm{PNN})_{4}\left(\mathrm{~N}_{3}\right)_{2}\right][15]$} & $2.078(1)$ & $1.176(2)$ & $1.145(3)$ & $177.9(2)$ & $128.9(1)$ \\
{$\left[\mathrm{Mo}(\mathrm{Cp})_{2}\left(\mathrm{~N}_{3}\right)_{2}\right][16]$} & $2.181(10)$ & $1.192(11)$ & $1.230(14)$ & $174.0(3)$ & $127.2(11)$ \\
{$\left[\mathrm{Mn}(\mathrm{bpy})\left(\mathrm{N}_{3}\right)_{4}\right][54]$} & $1.940(25)$ & $1.210(10)$ & $1.210(20)$ & $176.2(4)$ & $119.8(7)$ \\
\hline
\end{tabular}

$\left(\operatorname{trpn}=3,3^{\prime}, 3^{\prime \prime}\right.$-triaminopropylamine), $\mathrm{Cp}^{*}=$ pentamethylcyclopentadieny, $\mathrm{Sqn}=$ quinolinethiolate, $\mathrm{LDM}=N, N^{\prime}$-bis(salicylidene)-2,2'-dimethyl-1,3propanediamine, $\mathrm{PNN}=2$-( $p$-pyridyl)-4,4,5,5-tetramethylimidazoline-1-oxyl-3-oxide). 


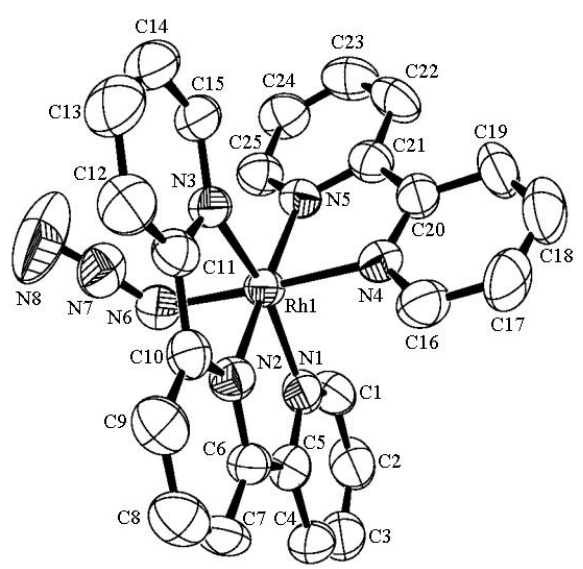

Figure 3. Structure of a formula unit and labeling scheme of a $\left[\mathrm{Rh}(\text { tpy })(\text { bpy })\left(\mathrm{N}_{3}\right)\right]^{2+}$ cation.

$\mathrm{N}-\mathrm{N}-\mathrm{N}$ molecule. One of the examples of the transition metal azide species are shown for the $\left[(\text { tpy })(b p y) R h\left(N_{3}\right)\right]^{2+}(b p y=$ 2,2'-bipyridine) cation in Fig. 3.

The structures of the Ru azide and bis(azide) complexes were compared with those of quantum mechanically calculated at the semi-empirical ZINDO/ 1 level of theory. ${ }^{10 \mathrm{c}, 56}$ They clearly show excellent agreement between the experimentally and theoretical data.

\section{Reactivity}

Although the reactivity study of covalent azides could be claimed to be complete both in organic synthesis and in main group chemistry, we will present a summary of the reactivity of the chemistry of inorganic azides. Due to the high polarity and the resulting increased reactivity, $\mathrm{IN}_{3}$ reacts very fast with metal iodides and metal halogenides as was shown in the substitution reaction of iodides of Group 13 elements. ${ }^{12 a}$

$$
\mathrm{IN}_{3}+\mathrm{EI}_{3} \rightarrow \mathrm{I}_{2} \mathrm{EN}_{3}+\mathrm{I}_{2}(\mathrm{E}=\mathrm{B}, \mathrm{Al}, \mathrm{Ga})
$$

It forms stable donor-acceptor adducts with many N-bases, including $\mathrm{N}_{3}{ }^{-}$, because it will be stabilized due to the higher coordination number at the central iodine atom. ${ }^{57}$ It acts as a Lewis acid in the formal addition of iodide to give $\mathrm{I}_{2} \mathrm{~N}_{3}{ }^{-58}$ Iodine azide can also behave as a Lewis base, which reacts with iodide cation to afford $\mathrm{I}_{2} \mathrm{~N}_{3}{ }^{+45}$

$$
\begin{aligned}
& \mathrm{IN}_{3}+\mathrm{N}_{3}^{-} \rightarrow \mathrm{I}\left(\mathrm{N}_{3}\right)_{2}^{-} \\
& \mathrm{IN}_{3}+\mathrm{NMe}_{4}^{+} \mathrm{I}^{-} \rightarrow \mathrm{NMe}_{4}^{+} \mathrm{I}_{2} \mathrm{~N}_{3}^{-} \\
& \mathrm{IN}_{3}+\mathrm{I}^{+} \rightarrow \mathrm{I}_{2} \mathrm{~N}_{3}{ }^{+}
\end{aligned}
$$

Below show an example of oxidative addition with $\mathrm{IN}_{3}$ from the area of organometallic chemistry. ${ }^{12 a}$

$$
\mathrm{IN}_{3}+\mathrm{R}_{3} \mathrm{Sb} \rightarrow \mathrm{R}_{3} \mathrm{SbI}\left(\mathrm{N}_{3}\right)
$$

In aqueous solvents, halogen azides hydrolyze in accordance to their bond polarity. ${ }^{59}$ Among them, iodine azide shows the

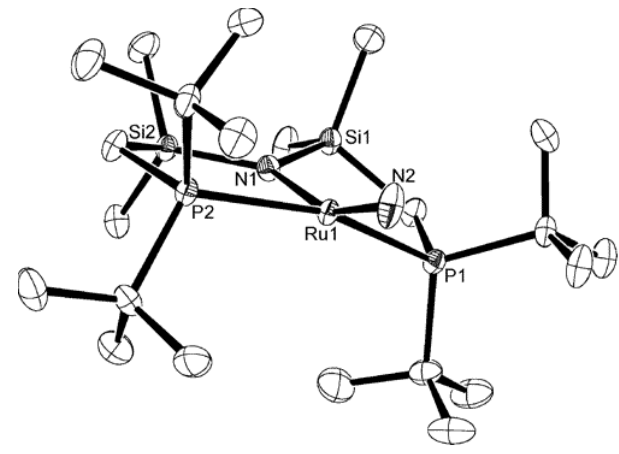

Figure 4. The crystal structure and selected atom labeling of the non-hydrogen atoms of one of two independent molecules of $\left[\left({ }^{t} \mathrm{Bu}_{2} \mathrm{PCH}_{2} \mathrm{SiMe}_{2}\right) \mathrm{N}\right] \mathrm{RuN}$.

extreme reactivity in spite of the relatively high polarity of the N-I bond.

$$
\mathrm{XN}_{3}+2 \mathrm{OH}^{-} \rightarrow \mathrm{N}_{3}^{-}+\mathrm{XO}^{-}+\mathrm{H}_{2} \mathrm{O}(\mathrm{X}=\mathrm{Cl}, \mathrm{Br}, \mathrm{I})
$$

Phosphazene derivatives have been synthesized using the Staudinger reaction starting with $\left(\mathrm{CF}_{3}\right)_{2} \mathrm{PN}_{3}$.

$$
\left(\mathrm{CF}_{3}\right)_{2} \mathrm{PI}+\mathrm{NaN}_{3} \rightarrow\left(\mathrm{CF}_{3}\right)_{2} \mathrm{PN}_{3}+\mathrm{NaI}
$$

$$
\left(\mathrm{CF}_{3}\right)_{2} \mathrm{PN}_{3}+\mathrm{PPh}_{3} \stackrel{-\mathrm{N}_{2}}{\longrightarrow} \mathrm{Ph}_{3} \mathrm{P}=\mathrm{N}-\mathrm{P}\left(\mathrm{CF}_{3}\right)_{2} \stackrel{+\left(\mathrm{CF}_{3}\right)_{2} \mathrm{PN}_{3 .}-\mathrm{N}_{2}}{\longrightarrow}
$$$$
\mathrm{Ph}_{3} \mathrm{P}=\mathrm{N}-\mathrm{P}\left(\mathrm{CF}_{3}\right)_{2}=\mathrm{N}-\mathrm{P}\left(\mathrm{CF}_{3}\right)_{2}
$$

As nitrogen atom donor, $\mathrm{Me}_{3} \mathrm{SiN}_{3}$ has been used in the preparation of new Se-N compounds such as $\mathrm{Se}_{2} \mathrm{NCl}_{3},(\mathrm{SeCl})_{2} \mathrm{~N}^{+}$, $\left(\mathrm{SeCl}_{2}\right)_{2} \mathrm{~N}^{+}$etc. Trimethylsilyl azide has been successfully used to the synthesis of polymeric sulfur nitride. ${ }^{61}$

$$
3 \mathrm{Me}_{3} \mathrm{SiN}_{3}+(\mathrm{NSCl})_{3} \rightarrow 3 / x(\mathrm{SN})_{\mathrm{x}}+3 \mathrm{Me}_{3} \mathrm{SiCl}+9 / 2 \mathrm{~N}_{2}
$$

Although transition metal azido complexes containing coordinated ligands are relatively more stable than covalent inorganic azides, their azido group undergoes various kinds of reaction to yield many interesting products. However azido complexes without chelating ligands such as $\mathrm{MCl}_{5} \mathrm{~N}_{3}(\mathrm{M}=\mathrm{Mo}, \mathrm{W})$ simply decompose in solution at room temperature to give $\mathrm{MNCl}_{3}$ with the evolution of $\mathrm{N}_{2}$ and $\mathrm{Cl}_{2}$ via the reductive elimination. For $\mathrm{MoX}_{3} \mathrm{~N}_{3}(\mathrm{X}=\mathrm{Cl}, \mathrm{Br})$ complexes, a dinitrogen molecule is removed with the concomitant appearance of $\mathrm{MoNX}_{3}$. However multi-azido complexes such as $\left[\mathrm{M}\left(\mathrm{N}_{3}\right)_{6}\right]$ which can be obtained from the reaction of $\mathrm{MF}_{6}$ with $\mathrm{Me}_{3} \mathrm{SiN}_{3}$, further ionized to give $\left[\mathrm{M}\left(\mathrm{N}_{3}\right)_{7}\right]^{-}$complexes by $[\mathrm{A}]^{+}\left[\mathrm{N}_{3}\right]^{-}$. Then, they easily decomposed in $\mathrm{CH}_{3} \mathrm{CN}$ or $\mathrm{SO}_{2}$ to give $\left[\mathrm{MN}\left(\mathrm{N}_{3}\right)_{4}\right]^{-}$shown in eq. $2 .^{14}$

$$
\begin{aligned}
{\left[\mathrm{M}\left(\mathrm{N}_{3}\right)_{6}\right]+[\mathrm{A}]^{+}\left[\mathrm{N}_{3}\right]^{-} \stackrel{>-20{ }^{\circ} \mathrm{C}}{\longrightarrow} } \\
{[\mathrm{A}]^{+}\left[\mathrm{MN}\left(\mathrm{N}_{3}\right)_{4}\right]^{-}+4 \mathrm{~N}_{2}(\mathrm{M}=\mathrm{Mo}, \mathrm{W}) }
\end{aligned}
$$

The reaction of paramagnetic [(PNP) RuCl] $\left(\mathrm{PNP}=\left({ }^{t} \mathrm{Bu}_{2}\right.\right.$ $\left.\left.\mathrm{PCH}_{2} \mathrm{SiMe}_{2}\right)_{2} \mathrm{~N}\right)$ ) complex with $\mathrm{NaN}_{3}$ or $\mathrm{Me}_{3} \mathrm{SiN}_{3}$ at room tem- 
perature to produce diamagnetic [(PNP)RuN] complex with a nonlinear P-Ru-P angle shown in Fig. $4 .^{13}$

The Ru-nitride bond distance of $1.627 \AA$ is consistent with a triple bond and assigned Ru(IV) and a $d^{4}$ electronic configuration. The thermal decomposition of the bis(azide) complex of $\left[\left(\mathrm{Cp}^{*}\right)_{2} \mathrm{Mo}\left(\mathrm{N}_{3}\right)_{2}\right]$ produces the terminal nitrido $\left[\left(\mathrm{Cp}^{*}\right)_{2} \mathrm{Mo} \equiv\right.$ $\mathrm{N}\left(\mathrm{N}_{3}\right)$ ] complex which is associated with the reductive elimination of one of bis(azide) ligand. ${ }^{16}$

Photolytic decomposition of the azidoiron(III) precursor $\left[(\right.$ cyclam $\left.) \mathrm{Fe}\left(\mathrm{N}_{3}\right)_{2}\right]\left[\mathrm{ClO}_{4}\right]$ (cyclam = 1,4,8,11-tetraazacyclotetradecane) in a frozen matrix yielded products of both $\mathrm{Fe}(\mathrm{II})$ complex by homolytic $\mathrm{Fe}-\mathrm{N}_{3}$ cleavage and $\mathrm{Fe}(\mathrm{V}) \mathrm{N}$ complex by heterolytic FeN-N 2 cleavage. However photolysis of [(cyclamac) $\left.\mathrm{Fe}\left(\mathrm{N}_{3}\right)\right]\left[\mathrm{ClO}_{4}\right]$ (cyclam-ac $=1,4,8,11$-tetraazacyclotetradecane-1-acetate) afforded only $[($ cyclam-ac $) \mathrm{Fe}(\mathrm{N})]\left[\mathrm{ClO}_{4}\right]$ species. $^{62}$

Kotera et al. have found that photolysis of $\left[\mathrm{Cp}^{*} \operatorname{Ir}(\mathrm{L})\left(\mathrm{N}_{3}\right)\right]$ ( $\mathrm{L}=2$-Spy (pyridinethiolate), 2-Sqn (quinolinethiolate)) resulted in insertion of a nitrogen atom originated from the azido ligand into the Ir-N(py) bond, giving imido/thiolato-type complex with a two-legged piano stool structure in eq. $3 .^{54}$

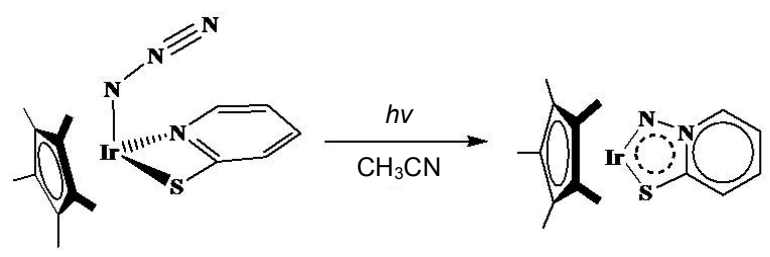

However, the strain-free azidoiridium(III) complexes containing 8-Sqn and Hbimi (benzimidazole-2-thiolate) did not exhibit a nitrogen atom insertion reaction on photolysis. Transition metal azide complexes can interestingly react with organic isocyanides to give complexes containing carbodiimido or $C$ coordinated tetrazolato groups by dipolar cycloaddition reaction. $^{63}$

Azide ions can function as a nitrogen source to form the nitride-bridged diruthenium complex $\left[\{\mathrm{Ru}(\mathrm{OR})(\mathrm{pyca})(\mathrm{bpy})\}_{2}\right.$ $(\mu-\mathrm{N})]^{+}$(pyca $=$pyridinecarboxylaye, $\left.\mathrm{R}=\mathrm{CH}_{3}, \mathrm{C}_{2} \mathrm{H}_{5}\right)$ in reactions of the pyca-bpy mixed-ligand type ruthenium complex of $c i s-\left[\mathrm{Ru}(\mathrm{Cl})(\mathrm{NO})(\mathrm{bpy})(\right.$ pyca)$]\left[\mathrm{PF}_{6}\right]$ with $\mathrm{NaN}_{3}$ in methanol and ethanol under refluxing condition. ${ }^{64}$ In the reaction, the formation of the product proceeded initially via oxidation of the ruthenium(II) species formed by a nucleophilic attack of $\mathrm{N}_{3}{ }^{-}$ to the nitrosyl group,

$$
\begin{aligned}
& {[\mathrm{Ru}(\mathrm{Cl})(\mathrm{NO})(\text { pyca })(\text { bpy })]^{+}+\mathrm{N}_{3}^{-}+\mathrm{ROH} \rightarrow} \\
& \quad[(\text { pyca })(\text { bpy })(\mathrm{RO}) \mathrm{RuNRu}(\mathrm{OR})(\text { bpy })(\text { pyca })]+\mathrm{N}_{2} \mathrm{O}+\mathrm{N}_{2}
\end{aligned}
$$

Another example shows that the azido complex can be easily oxidized by Ce(IV) via 1-electron transfer, ${ }^{65}$

$$
\begin{aligned}
& c i s-\left[\mathrm{Os}(\mathrm{tpy}) \mathrm{Cl}_{2}\left(\mathrm{~N}_{3}\right)\right]+\mathrm{Ce}(\mathrm{IV}) \rightarrow \\
& \qquad i s-\left[\mathrm{Os}(\mathrm{tpy}) \mathrm{Cl}_{2}\left(\mathrm{~N}_{3}\right)\right]^{+}+\mathrm{Ce}(\mathrm{III})
\end{aligned}
$$

Uranium nitrides offer potential as future nuclear fuels and

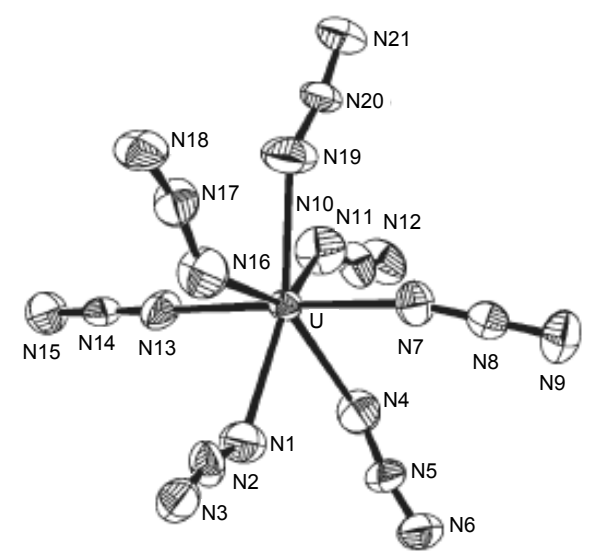

Figure 5. Molecular structure of the $\left[\mathrm{U}\left(\mathrm{N}_{3}\right)_{7}\right]^{3-}$ anion.

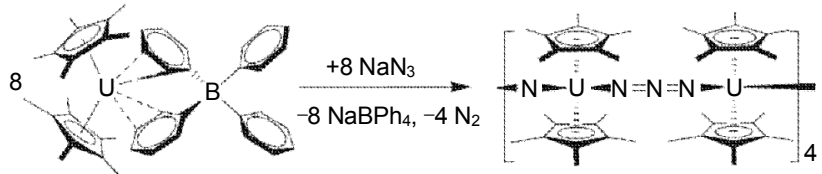

Figure 6. Synthesis of $\left[\left(\mathrm{C}_{5} \mathrm{Me}_{5}\right)_{2} \mathrm{U}(\mu-\mathrm{N}) \mathrm{U}\left(\mu-\mathrm{N}_{3}\right)\left(\mathrm{C}_{5} \mathrm{Me}_{5}\right)_{2}\right]_{4}$.

as probes of metal ligand multiple bonding involving the $f$-block actinide metals. However, few molecular examples are available for study owing to the difficulties in synthesis. The $\mathrm{UN}_{21}{ }^{3-}$ ion, which was synthesized and characterized by Crawford et al. as the $\left(\mathrm{Bu}_{4} \mathrm{~N}\right)_{3}\left[\mathrm{U}\left(\mathrm{N}_{3}\right)_{7}\right]$ salt, is not only the first homoleptic azide of an actinide but also the first structurally characterized heptaazide in Fig. $5{ }^{12 \mathrm{f}}$

Recent advances in organoactinide chemistry by Evans et al. have provided another route to uranium nitride complexes that expands the options for developing uranium nitride chemistry. ${ }^{66}$

\section{Perspective}

For long time, azide chemistry has been a more academic area of research. However, in recent times new possible applications in areas of applied chemistry are emerging. Some of these areas - the list may by far not be complete - are:

1) Utilization and extension of the so-called "click-chemistry" introduced by Sharpless in $2001^{67,68}$ which describes chemistry tailored to generate substances quickly and reliably by joining small units together. This is inspired by the fact that nature also generates substances by joining small modular units. One of the most popular reactions within the click chemistry philosophy is the azide alkyne Huisgen cycloaddition using a $\mathrm{Cu}$ catalyst at room temperature discovered concurrently and independently by the groups of K. Barry Sharpless and Morten Meldal. This was an improvement over the same reaction first popularized by Rolf Huisgen in the 1970s, albeit at elevated temperatures in the absence of water and without a $\mathrm{Cu}$ catalyst.

2) Extending molecular azide chemistry into the field of novel materials preparation. An example could be the synthesis of new uranium nitrides as advanced temperature stable nuclear elements. Uranium nitrides have been proposed as possible 
replacements for uranium oxide pellets in nuclear reactors. ${ }^{66}$ Therefore, the synthesis of uranium complexes containing nitrogen rich azide ligands as precursors may be a possible route to the synthesis of new uranium nitrides when the complexes are pyrolysed. For example, the pyrolysis of covalent azides (XN1N2N3) often occurs via cleavage of the N1-N2, bond resulting initially in $\mathrm{XN}$ and $\mathrm{N}_{2}{ }^{10 a, 12 \mathrm{a}}$ and therefore it would be interesting to investigate the synthesis and characterisation of uranium azides and the subsequent pyrolysis of these compounds.

3) There has been extensive theoretical debate about the stability of nonmolecular polymeric phases of nitrogen at ambient conditions, particularly the $c g-\mathrm{N}$ phase. ${ }^{69-72}$ Quantum mechanical (QM) calculations have characterized and tested the stability of high-pressure, nonmolecular amorphous structures generated through quenching hot atomic nitrogen gas. Upon decompression, the polymeric structures become destabilized when adjacent singly coordinated atoms within the nitrogen network break away to form diatomic molecules. ${ }^{73}$ This "unraveling" of the polymeric structure propagates through the polymer and ultimately results in a back transformation to a molecular phase. QM calculations have shown that passivation of the terminal ends of the singly coordinated atoms with an impurity, such as hydrogen or ammonia, produced an increase in the stability of the amorphous polynitrogen structures upon decompression. ${ }^{74}$ Using these quantum mechanical simulations as a guide, an experimental investigation into the structure, stability and highpressure modifications of $\mathrm{HN}_{3}$ seems to be extremely important.

\section{References}

1. Candan, P.; Manzano, C.; Losada, M. Nature 1976, 262, 715.

2. White, R. E.; Coon, M. J. Annu. Rev. Biochem. 1980, 49, 315.

3. Averill, B. A. Chem. Rev. 1996, 96, 2951.

4. (a) Nugent, W. A.; Mayer, J. M. Metal-Ligand Multiple Bonds; Wiley-Interscience: New York, 1988. (b) Berry, J. F.; Bill, E.; Bothe, E.; George, S. D.; Mienert, B.; Neese, F.; Wieghardt, K. Science 2006, 312, 1937. (c) Mazumder, B.; Chirico, P.; Hector, A. L. Inorg. Chem. 2008, 47, 9684. (d) Concepcion, J. J.; Jurss, J. W.; Templeton, J. L.; Meyer, T. J. J. Am. Chem. Soc. 2008, 130, 16462.

5. Allen, A. D.; Senoff, C. W. Chem. Commun. 1965, 621.

6. Mackay, B. A.; Fryzuk, M. D. Chem. Rev. 2004, 104, 385.

7. Leising, R. A.; Kubow, S. A.; Churchill, M. R.; Buttrey, L. A.; Ziller, J. W.; Takeuchi, K. Inorg. Chem. 1990, 29, 1306.

8. Greenwood, N. N.; Earnshaw, A. Chemistry of the Elements; Pergamon: Oxford, 1984.

9. (a) Hantzsch, A.; Schümann, M. Ber. Dtsch. Chem. Ges. 1900, 33, 522. (b) Geissler, P.; Klapötke, T. M.; Kroth, K.-H. Spectrochim. Acta 1995, 51A, 1075 .

10. (a) Tornieporth-Oetting, I. C.; Klapötke, T. M. Angew. Chem. Int. Ed. 1995, 34, 511. (b) Sima, J. Coord. Chem. Rev. 2006, 250, 2325. (c) Strähle, J. Z. Anorg. Allg. Chem. 2007, 633, 1757. (d) Suzuki, T.; Kotera, M.; Takayama, A.; Kojima, M. Polyhedron 2009, 28, 2287 and references therein.

11. Tornieporth-Oetting, I. C.; Klapötke, T. M. Combustion Efficiency and Air Quality; Hargittai, I., Vidoczy, T., Eds.; Plenum: New York, 1995.

12. (a) Dehnicke, K. Adv. Inorg. Chem. Radiochem. 1983, 26, 169. (b) Klapötke, T. M. Chem. Ber. 1997, 130, 443. (c) Seok, W. K.; Yim, S. B.; Klapötke, T. M.; White, P. S. J. Organomet. Chem. 1998, 559, 165. (d) Massoud, S. S.; Mautner, F. A.; Abu-Youssef, M. A. M.; Shuaib, N. M. Polyhedron 1999, 18, 2061. (e) Seok,
W. K.; Lee, H. N.; Kim, M. Y.; Klapötke, T. M.; Dong, Y. K.; Yun, H. J. Organomet. Chem. 2002, 654, 170. (f) Crawford, M.-J.; Ellern, A.; Mayer, P. Angew. Chem. Int. Ed. 2005, 44, 7874 and references therein. (g) Ercan, F.; Ates, B. M.; Aksu, L.; Soezeri, H.; Ercan, I.; Akatol, O. Z. Kristallogr. 2007, 222, 498.

13. Walstrom, A.; Pink, M.; Yang, X.; Tomaszewski, J.; Baik, M.-H.; Caulton, K. G. J. Am. Chem. Soc. 2005, 127, 5330.

14. Haiges, R.; Boatz, J. A.; Bau, R.; Schneider, S.; Schroer, T.; Yousufuddin, M.; Christe, K. O. Angew. Chem. Int. Ed. 2005, 44, 1860.

15. Zhang, L.; Li, L.-C.; Jiang, Z.-H.; Yan, S.-P.; Shen, P.-W. Inorg. Chimica Acta 2001, 320, 141.

16. Shin, J. H.; Bridgewater, B. M.; Churchill, D. G.; Baik, M.-H.; Friesner, R. A.; Parkin, G. J. Am. Chem. Soc. 2001, 123, 10111.

17. (a) Belton, P. S.; Woollins, J. D. Magn. Reson. Chem. 1986, 24 , 1080. (b) Passmore, J.; Schriver, M. J. Inorg. Chem. 1988, 27, 2749.

18. Winnewisser, B. P. J. Mol. Spectrosc. 1980, 82, 220.

19. Christe, K. O.; Wilson, W. W.; Dixon, D. A.; Khan, S. I.; Bau, R.; Metzenthin, T.; Lu, R. J. Am. Chem. Soc. 1993, 115, 1836.

20. Almenningen, A.; Bak, B.; Jansen, P.; Strand, T. G. Acta Chem. Scand. 1973, 27, 1531.

21. Christe, K. O.; Christen, D.; Oberhammer, H.; Schack, C. J. Inorg. Chem. 1984, 23, 4283 .

22. Ebsworth, E. A. V.; Jenkins, D. R.; Mays, M. J.; Sugden, T. M. Proc. Chem. Soc. 1963, 21.

23. Muidoch, J. D.; Rankin, D. W. H. Chem. Commun. 1972, 748.

24. Christen, D.; Mack, H. G.; Schatte, G.; Willner, H. J. Am. Chem. Soc. 1988, 110, 707.

25. Cook, R. L.; Gerry, M. C. L. J. Chem. Phys. 1970, 53, 2525.

26. Johnson, J. P.; MacLean, G. K.; Passmore, J.; White, P. S. Can. J. Chem. 1989, 67, 1687

27. Ang, H. G.; Kwik, W.-L.; Lee, Y. W.; Oberhammer, H. Inorg. Chem. 1994, 33, 4425.

28. Ang, H. G.; Kwik, W.-L.; Lee, Y. W.; Liedle, S.; Oberhammer, H. J. Mol. Struct. 1992, 268, 389.

29. Ang, H. G.; Lee, Y. W.; Novak, I.; Potts, A. W. J. Phys. Chem. 1994, 98, 12526.

30. Glukhovtsev, M. N.; Schleyer, P. v. R. Chem. Phys. Lett. 1992, $198,547$.

31. Harcourt, R. D. J. Mol. Struct. 1993, 300, 245.

32. Harcourt, R. D. Chem. Eng. News 1985, 53(3), 77.

33. Harcourt, R. D. New J. Chem. 1992, 16, 667.

34. Harcourt, R. D. J. Mol. Struct. (Theochem) 1992, 259, 155 and references therein.

35. Harcourt, R. D.; Sillitoe, J. F. Aust. J. Chem. 1974, 27, 691.

36. Richardson, W. C.; Setser, D. W. Can. J. Chem. 1969, 47, 2725.

37. Alexander, M. H.; Werner, H.-J.; Dagdigina, P. J. J. Chem. Phys. 1988, 89, 1388.

38. Kajimoto, O.; Yamamoto, T.; Fueno, T. J. Phys. Chem. 1979, 83, 429.

39. Otto, M.; Lotz, S. D.; Frenking, G. Inorg. Chem. 1992, 31, 3647.

40. Schulz, A.; Tornieporth-Oetting, I. C.; Klapötke, T. M. Inorg. Chem. 1995, 34, 4343.

41. Hargittai, M.; Tornieporth-Oetting, I. C.; Klapötke, T. M.; Kolonitz, M.; Hargittai, I. Angew. Chem. Int. Ed. 1993, 32, 759.

42. Buzek, P.; Klapötke, T. M.; Schleyer, P. v. R.; Tornieporth-Oetting, I. C.; White, P. S. Angew. Chem. Int. Ed. 1993, 32, 275.

43. Hargittai, M.; Molnar, J.; Klapötke, T. M.; Tornicporth-Oetting, I. C.; Kolonitz, M.; Hargittai, I. J. Phys. Chem. 1994, 98, 10095.

44. Munz, H.-O.; Bodenseh, H.-K.; Klapötke, T. M. 14th Colloquium on High-Resolution Molecular Spectroscopy, September 11-15, Dijon, 1995.

45. Tornieporth-Oetting, I. C.; Buzek, P.; Schleyer, P. v. R.; Klapötke, T. M. Angew. Chem. Int. Ed. Engl. 1992, 31, 1338.

46. Tornieporth-Oetting, I. C.; Klapötke, T. M.; Schulz, A.; Buzek, P.; Schleyer, P. v. R. Inorg. Chem. 1993, 32, 5640.

47. (a) Schulz, A.; Tornieporth-Oetting, I. C.; Klapötke, T. M. Inorg Chem. 1995, 34, 4343. (b) Klapötke, T. M. In Moderne Anorganische Chemie, 3rd ed.; Riedel, E., Ed.; Walter de Gruyter: Berlin, 2007. 
48. Janoschek, R. Angew. Chem. Int. Ed. 1993, 32, 230.

49. Holleman, A. F.; Wiberg, E.; Niberg, N. Lehrbuch der Anorganischen Chemie; Walter de Gruyter: Berlin-New York, 1985.

50. Campana, C. F.; Lo, F. Y.-K.; Dahl, L. F. Inorg. Chem. 1979, 18 , 3060 .

51. Schleyer, P. v. R.; Kos, A. J. Tetrahedron 1983, 39, 1141.

52. Schleyer, P. v. R.; Kaufmann, E.; Kos, A, J.; Mayr, H.; Chandrasekhar, J. Chem. Commun. 1986, 1583.

53. Kotera, M.; Sekioka, Y.; Suzuki, T. Inorg. Chimica Acta 2008 , $361,1479$.

54. Dave, B. C.; Czemuszewicz, R. S. J. Coord. Chem. 1994, 33, 257.

55. Reed, A. E.; Curtiss, L. A.; Weinhold, F. Chem. Rev. 1988, 88, 899.

56. Seok, W. K.; Yim, S. B.; Lee, H. N.; Klapötke, T. M. Z. Naturforsch. 2000, 55b, 462.

57. Dörner, H.; Dehnicke, K.; Massa, W.; Schmidt, R. Z. Naturforsch. B 1983, 38, 437.

58. Dübgen, R.; Dehnicke, K. Naturwissenschaften 1978, 65, 535.

59. Dehnicke, K. Angew. Chem. Int. Ed. 1967, 6, 240.

60. Ang, H. G.; Cai, Y. M.; Kwik, W. L. 11th Winter Fluorine ACS Conference, Lecture 35, St. Petersburg, USA, 1993.

61. Siivari, J.; Chivers, T.; Laitinen, R. Angew. Chem. Int. Ed. 1992 , 31,1518 .

62. Aliaga-Alcalde, N.; George, S. D.; Mienert, B.; Bill, E.; Wieghardt, K.; Neese, F. Angew. Chem. Int. Ed. 2005, 44, 2908. (b) Scepaniak,
J. J.; Fulton, M. D.; Bontchev, R. P.; Duesler, E. N.; Kirk, M. L.; Smith, J. M. J. Am. Chem. Soc. 2008, 130, 10515.

63. (a) Kim, W. S.; Kim, Y.-J.; Lee, S. W. Bull. Korean Chem. Soc. 2002, 23, 1177 (b) Kim, Y.-J.; Lee, S.-H.; Lee, S.-H; Jeon, S. I.; Lim, M. S.; Lee, S. W. Inorg. Chimica Acta 2005, 358, 650.

64. Matsumura, S.; Shikano, K.; Oi, T.; Suzuki, N.; Nagao, H. Inorg. Chem. 2008, 47, 9125.

65. Demadis, K. D.; Meyer, T. J.; White, P. S. Inorg. Chem. 1998, 37, 3610.

66. Evans, W. J.; Kozimor, S. A.; Ziller, J. W. Science 2005, 309, 1835.

67. Kolb, H. C.; Finn, M. G.; Sharpless, K. B. Angew. Chem. Int. Ed. 2001, 40, 2004.

68. Evans, R. A. Aust. J. Chem. 2007, 60, 384.

69. Erments, M. I.; Gavriliuk, A. G.; Serebryanaya, N. R.; Trojan, I. A.; Dzivenko, D. A.; Boehler, R.; Mao, H. K.; Hemley, R. J. J. Chem. Phys. 2004, 121, 11296.

70. Erments, M. I.; Gavriliuk, A. G.; Trojan, I. A.; Dzivenko, D. A.; Boehler, R. Nature Materials 2004, 121, 11296.

71. Erments, M. I.; Popov, M. Y.; Trojan, I. A,; Denisov, V. N.; Boehler, R.; Hemley, R. J. J. Chem. Phys. 2004, 120, 10618.

72. Hanfland, M.; Lorenzen, M.; Wassilew-Ruel, C.; Zontone, F. Rev. High Pressure Sci. Technol. 1998, 7, 787.

73. McMahan, M. K.; Lasar, R. Phys. Rev. Lett. 1985, 54, 1929.

74. Martin, R. M.; Needs, R. J. Phys. Rev. B 1986, 34, 5082. 